\title{
Peran Media Komunikasi Digital Pada Pola Komunikasi Guru dan Murid
}

\author{
Rahajeng Puspitosari, Arbi Cristional Lokananta \\ Rahajeng.puspitosari@budiluhur.ac.id, arbilokananta@budiluhur.ac.id \\ Universitas Budi Luhur Jakarta, Jl. Ciledug Raya, Petukangan Utara, Jakarta Selatan, 12260
}

Submitted: 19 Mei 2021, Revised: 10 Juni 2021, Accepted : 12 Juni 2021

\begin{abstract}
Abstrak
Dahulu komunikasi terbatas hanya dalam ruang kelas antara guru dan murid. Keharmonisan komunikasi antara guru dan murid adalah hal yang perlu diperhatikan agar lebih maksimal dalam kegiatan pembelajaran dan tercapainya tujuan dari pembelajaran tersebut. Sering terjadi kendala dalam penyebaran informasi pembelajaran selama ini yang diakibatkan oleh terbatasnya ruang komunikasi. Hal ini menjadikan penyebaran informasi menjadi tidak begitu efektif dan sering kali terjadi kesalahan dalam pemahaman informasi (miss communication). Namun, perkembangan teknologi komunikasi saat ini membuat penyebaran informasi menjadi lebih mudah. Internet merupakan salah satu produk teknologi menjadi sarana penyebaran informasi yang mudah diakses masyarakat luas. Demikian juga dengan Media digital yang dapat diakses masyarakat melalui ponsel pintar (smartphone) kapan pun dan di mana pun. Namun ternyata ada perubahan pada pola komunikasi antara guru dan murid dengan penggunaan media baru tersebut. Jarak dan pola komunikasi formal menjadi berubah dengan adanya media baru ini. Oleh karena itu, penelitian ini menggunakan teori-teori dan konsep-konsep yang berkaitan dengan media baru, media sosial, dan pola komunikasi. Jenis penelitian ini adalah deskriptif kualitatif, obyek penelitiannya adalah pola komunikasi antara guru dan murid di SMK PGRI Larangan dalam menggunakan media komunikasi digital. Hasil analisis data serta hasil wawancara menunjukkan pola komunikasi yang terjadi di dalam grup WhatsApp guru dan Murid SMK PGRI Larangan terjadi banyak arah, baik secara vertikal, horizontal maupun diagonal. Analisis dan hasil wawancara menunjukkan pula, murid merasa lebih fleksibel ketika berkomunikasi dengan guru menggunakan grup WhatsApp ketimbang bertatap muka secara langsung.
\end{abstract}

Kata kunci: media digital, pola komunikasi, guru, murid

\section{Role of Digital Communication Media on the Teacher and Student Communication Pattern}

\begin{abstract}
In the past communication was limited only in the classroom between teachers and students. Harmonious communication between teacher and student is the important things to be more maximal in learning activities and achieving the objectives of the learning. many obstacles caused by limited communication space. It might be the spread of communication cannot be effective and being miss communication. But the development of communication technology make spread the information easier. Internet is one of technology product beinge the media for spread the information can access for the community. Similarly with the digital media can access by smartphone everytime and everywhere. But there is the change of communication pattern between teacher and student with use the new media. Therefor, this research use theories and concepts related to new media, social media and communication pattern. Types of research is Descriptive Qualitative, the objective is the communication pattern between teacher and student PGRI Larangan when using digital communication media. Data analysis result and interview result show the communication pattern which happen at WhatsApp group teacher and student SMK PGRI Larangan happen vertically, horizontal and diagonal. Analysis and interview result also show, the student feel more flexible to communication with teacher with WhatsApp Group than directly communication.
\end{abstract}

Keywords : digital media, communication pattern, teacher and students 


\section{PENDAHULUAN}

Seiring perkembangan teknologi dan masyarakat penggunannya, studi komunikasi kini kian dinamis. Teknologi menjadi bagian yang vital dalam beberapa pendekatan komunikasi, sehingga teknologi dengan komunikasi memilik hubungan yang berkesinambungan. Misalnya ilmuwan matematika Shanon and Weaver yang menitikberatkan komunikasi pada gangguan dan medium. Shanon melakukan penelitian untuk perusahaan telekomunikasi tentu berusaha untuk mengukur capacity dan eficience teknologi komunikasi sebagai sarana perubahan tanda (simbol).(Sukmi, n.d.)

Pada era kemajuan teknologi saat ini, informasi merupakan hal krusial. Semua lapisan masyarakat untuk berkembang dan berinteraksi memiliki hak mendapatkan informasi. Sehingga informasi menjadi salah satu kebutuhan manusia yang penting sebagai sumber pengetahuan, pemahaman dan pengertian akan hal-hal yang terjadi di sekitar sehingga peran informasi sangatlah berharga bagi manusia. Masyarakat memasuki era informasi, sehingga jaringan informasi perlu dibangun dan dikembangkan sebagai sarana penyalur informasi. Dari pernyataan tersebut, dapat dipahami bila masyarakat harus bersikap selektif dalam memilih media untuk memenuhi kebutuhan informasi dalam kehidupan sehari-harinya.

Perkembangan informasi yang sangat pesat dengan kemajuan teknologi yang mendukung, dapat mempermudah dalam memenuhi kebutuhan informasi. Ada beberapa jenis komunikasi salah satunya adalah komunikasi massa. Komunikasi massa merupakan komunikasi dimana pesan-pesan disampaikan melalui media massa (media cetak, media elektronik, media baru). Media massa adalah sarana komunikasi yang menyebarkan pesan secara serempak, cepat kepada khalayak yang luas dan heterogen (berbeda-beda) dengan menggunakan sistem cetak, elektronik maupun digital yang mampu mengatasi hambatan ruang dan waktu. Sehingga hal ini menjadi kelebihan komunikasi menggunakan media massa dibandingkan dengan komunikasi lain (kelompok atau publik). Bahkan media massa mampu menyebarkan hampir seketika pada waktu yang tak terbatas (Nurudin, 2007). Salah satu media massa yang digunakan dalam berkomunikasi untuk mendapatkan informasi saat ini adalah internet, karena merupakan jaringan global yang bebas hambatan.

Dengan perkembangan yang pesat di bidang teknologi komunikasi, pemahaman mengenai teknologi komunikasi menjadi banyak sorotan untuk ahli-ahli komunikasi, slaah satunya Everett M. Rogers (1986) yang melihat bahwa teknologi komunikasi merupakan perangkat keras dalam struktur organisasi yang mengandung nilai-nilai sosial, yang memungkinkan setiap individu mengumpulkan, memproses dan melakukan saling tukar informasi dengan individu lain. Definisi Rogers tersebut menunjukkan bahwa teknologi komunikasi mempunyai beberapa karakterisitik. Pertama, teknologi komunikasi berkaitan dengan perangkat keras atau alat. Kedua, teknologi komunikasi muncul dalam suatu struktur ekonomi, sosial dan politik tertentu. Ketiga, teknologi komunikasi membawa nilai-nilai tertentu dari struktur di atas. Keempat, teknologi komunikasi berhubungan dengan perangkat keras di bidang komunikasi. Sebagai perangkat keras, lebih lanjut dikatakan oleh Rogers (1986), teknologi komunikasi mengkondisikan penggunanya unutk melakukan demassifikasi dalam mengontrol pesan, menyesuaikan diri dengan standar teknis pemakaian teknologi 
komunikasi serta meningkatkan interaksi dengan individu lain tanpa mengenal hambatan jarak. (Kurmia, 2005). Teknologi komunikasi memunculkan media baru.

McQuail (2010), ada perubahan-perubahan penting yang berhubungan dengan munculnya media baru, yaitu:

1. Digitalisasi dari konvergensi semua aspek dari media

2. Interaktivitas dan konektivitas jejaring yang meningkat

3. Mobilitas dan delokasi pengiriman dan penerimaan (pesan)

4. Adaptasi publikasi dan peran-peran khalayak

5. Munculnya beragam bentuk baru dari media 'gateaway' yaitu pintu masuk untuk mengakses informasi pada web atau untuk mengakses web itu sendiri

6. Fragmentasi dari kaburnya 'institusi media'. (Hamidati \& Junaedi, 2011)

Salah satu jenis media baru adalah media sosial. Media sosial dapat dengan mudah diakses oleh masyarakat melalui telepon genggam dengan mengunduh aplikasi mobile tersebut. Penelitian ini fokus pada pemanfaatan media sosial WhatsApp, karena merupakan media sosial yang paling popular di masyarakat. WhatsApp merupakan sebuah aplikasi media sosial yang memiliki berbagai macam fitur yang dirancang untuk memudahkan penggunanya dalam berkomunikasi. Sebelumnya peneliti telah melakukan pengamatan pada salah satu Sekolah Menengah Atas di wilayah Tangerang yaitu Sekolah Menengah Kejuruan (SMK) PGRI Larangan. Berdasarkan observasi yang peneliti lakukan bahwa saat ini pihak sekolah, guru, dan murid selalu melakukan komunikasi dan menyebarkan informasi terkait pembelajaran melalui WhatsApp Group.

WhatsApp Messenger adalah aplikasi perpesanan gratis yang tersedia untuk Android dan ponsel cerdas lainnya. WhatsApp menggunakan koneksi internet telepon (4G/3G/2G/EDGE atau Wi-Fi) yang memungkinkan untuk mengirim pesan dan menelepon seseorang baik teman maupun keluarga. Berkembang dari SMS ke WhatsApp untuk mengirim dan menerima pesan, panggilan, video, dokumen dan pesan suara.(WhatsApp,n.d.). WhatsApp menjadi salah satu media komunikasi yang sering digunakan oleh guru dan murid di SMK PGRI Larangan. Hampir tiap komunikasi dan informasi disampaikan oleh guru melalui WhatsApp Group tersebut. SMK PGRI Larangan berada di J1. Siswa No. 5 Larangan Indah, Kec. Larangan, Kota Tangerang, Banten dan memiliki Kepala Sekolah bernama Bapak Riskon Arifiyanto.(SMK PGRI,n.d.)

Group WhatsApp menjadi media komunikasi yang digunakan antara pihak sekolah yaitu guru dengan murid-murid yang masing-masing group berdasarkan kelompok kelas dimana semua murid dan guru menjadi angoota group. Informasi seputar kegitana belajar mengajar dan pengumuman dari sekolah menjadi fokus utamanya. Diskusi materi belajar, tugas individu maupun kelompok dan masih banyak lainnya. Namun dari serangkaian dampak positif, media komunikasi digital juga memberikan dampak negatif, diantaranya melalui pola komunikasi, sikap dan perilaku. Melalui hasil penelitian dan observasi yang dilakukan peneliti menunjukkan bahwa murid cenderung berperilaku melanggar norma kesopanan seperti merasa dekat dan nyaris tidak terdapat gap komunikasi antara guru dan murid. Hal inilah yang mengkhawatirkan bahwasanya diperlukan komunikasi yang harmonis dan efektif namun tidak menyimpang dari norma-norma kesopanan. 
Adapun masalah penelitian ini meliputi: (a) Bagaimana tingkat pemahaman guru dan murid mengenai media digital? (b) Bagaimana pola komunikasi antara guru dan murid dengan menggunakan media komunikasi digital? (c) Bagaimana pola komunikasi guru dan murid dalam berkomunikasi melalui WhatsApp?

Adapun tujuan ini diperjelas yaitu: (1) Ditemukan dan teridentifikasi peran media digital pada pola komunikasi antara guru dan murid (2) Diperoleh bentuk-bentuk penyimpangan kesopanan akibat komunikasi menggunakan media digital (3) Diperoleh pola komunikasi antara guru dan murid dalam percakapan melalui WhatsApp Group (4) Publikasi Nasional ataupun publikasi Internasional (5) Publikasi di jurnal skala nasional maupun internasional (6) Dapat menyusun draft buku ajar yang ber-ISBN.

Guna memperkuat hasil penelitian maka diperlukan landasan teori, Adapun teori-teori yang digunakan yaitu Teori Media Baru, Media Sosial, Fungsi dan Jenisnya. Media baru (new media) merupakan alat atau sarana dalam menyampaikan pesan pada khalayak luas dengan menggunakan teknologi digital atau disebut juga sebagai jaringan teknologi komunikasi dan informasi, yang termasuk kategori media baru adalah internet, website, computer multimedia. Tetapi internet lebih dikenal sebagai media baru, sebenarnya internet merupakan salah satu bentuk media baru. Media cetak mengandalkan percetakan (press), media elektronik mengandalkan sinyal transmisi, sedangkan media baru mengandalkan komputer. Media baru memungkinkan orang untuk membuat, memodifikasi, dan berbagi dengan orang lain, menggunakan alat yang relatif sederhana yang sering gratis atau murah. Media baru membutuhkan komputer atau perangkat mobile dengan akses internet (Vera, 2016)

Kehadiran media baru dalam segala bentuk dan fungsinya ini tentu saja tidak begitu saja menggeser media lama atau tradisional yang ada selama ini seperti terlihat dalam pengelompokkan era perkembangan teknologi komunikasi yang dilakukan oleh Rogers (1986) namun tetap dibutuhkan masyarakat untuk menjadi sumber informasi sesuai dengan karakteristiknya masing-masing. Perbedaan yang nampak antara media baru dan lama yang jelas mencuat adalah dari segi-segi penggunaannya secara individual yang diungkapkan oleh McQuail (2000) melalui tingkat interaktif penggunaan media yang diindikasikan oleh rasio respon pengguna terhadap pengirim pesan, tingkat sosialiasi pengguna dimana media baru lebih bersifat individual dan bukan bersifat interaksi sosial secara langsung, tingkat kebebasan dalam penggunaan media, tingkat kesenangan dan menariknya media yang digunakan seusia keinginan serta tingkat privasi yang tinggi untuk penggunaan media baru.(Kurmia,2005)

Menurut Andreas Kaplan dan Michael Haenlein mendefinisikan media sosial sebagai sebuah kelompok aplikasi berbasis internet yang dibangun diatas dasar ideologi dan teknologi Web 2.0 dan memungkinkan penciptaan dan pertukaran user-generated content. Web 2.0 menjadi platform dasar media sosial. Media sosial ada dalam berbagai bentuk yang berbeda, termasuk social network, forum internet weblogs, social blogs, micro blogging, wikis, podcasts, gambar, video, rating dan bookmark social. Menurut Andreas Kaplan dan Haenlein ada enam jenis media sosial, yaitu: proyek kolaborasi (misal: wikipedia), blog dan micro blogs (misal: twitter), komunitas konten (misal: youtube), situs jaringan sosial (misal: 
facebook, instagram), virtual game (misal: world of warcraft) dan virtual social (misal: second life). (Ii \& Pustaka, 2011).

"Media sosial merupakan media yang digunakan untuk mempublikasikan konten seperti profil, aktivitas, pendapat pengguna. Media sosial juga memberikan ruang bagi komunikasi dan interaksi dalam jejaring sosial di ruang siber" (Nasrullah, 2016). Media sosial memiliki ciri-ciri yang tidak lepas dari berbagai ciri-ciri dari media sosial yang banyak digunakan hingga saat ini. Berikut beberapa karakteristik yang terdapat pada media sosial, partisipasi, keterbukaan, perbincangan, keterhubungan. Berdasarkan karakteristik tersebut maka WhatsApp dapat dikategorikan sebagai salah satu bentuk media sosial.

Peran WhatsApp sebagai media pembelajaran terutama di masa pandemic covid-19 sangat terasa, tidak semua murid mempunyai computer pribadi di rumahnya padahal proses pembelajaran selama pandemic adalah belajar di rumah, tentunya memerlukan perangkat teknologi untuk kelangsungan proses belajar tersebut. WhatsApp yang bisa diakses dengan mudah melalui smartphone dan harganya cukup terjangkau menjadi alternatif alat pembelajaran daring.

Terdapat beberapa komponen komunikasi yang saling berhubungan satu dengan lainnya. Komunikator, pesan dan komunikan merupakan aspek penting dalam berkomunikasi. Efektif atau tidaknya penyebaran informasi dipengaruhi pula oleh komponen-komponen komunikasi di dalamnya. Pengirim pesan merupakan komponen informasi yang pertama.

Komunikator atau yang biasa dikenala dengan komunikator merupakan orang yang memiliki gagasan atau pesan yang akan disampaikan kepada komunikan. Selanjutnya encoding atau penyandian yaitu sebuah proses memberi kode pada gagasan ke dalam simbol tertentu baik non verbal maupun secara verbal. Selanjutnya elemen terakhir merupakan komunikan. Komunikan atau penerima pesan merupakan seseorang yang mendapatkan pesan dari komunikator baik secaara verbal maupun non verbal dan menggunakan media-media pendukung. (Pratama et al)

Dalam bidang pendidikan, proses penyebaran informasi dapat dilakukan oleh sekolah kepada murid, guru kepada murid, maupun sekolah kepada keluarga (orang tua murid). Penyebaran informasi dari organisasi sekolah kepada murid termasuk ke dalam komunikasi organisasi pendidikan dengaen stakeholder. Tujuan dari komunikasi organisasi pendidikan kepada stakeholder bertujuan untuk mengetahui kegiatan yang dilakukan oleh organisasi sehingga sifat dari komunikasi ini adalah informatif (Mukaromah, 2002)

Kontribusi teknologi informasi dan komunikasi (TIK) dalam teknologi pembelajaran mencangkup aspek infrastuktur informasi dan telekomunikasi, sumber daya manuasia dan acuan atau produk hukum telematika sehingga dapat berperan untuk membelajarkan manusia dengan mengembangkan dan atau aneka sumber belajar. Secara umum paling tidak ada dua kedudukan TIK dalam pembelajaran, yaitu pertama, sebagai pendorong komunitas pendidikan untuk lebih apresiatif dan proaktif dalam maksimalisasi potensi pendidikan. Keduua, memberikan kesempatan luas kepada peserta didik dalam memanfaatkan setiap potensi yang ada, yang diperoleh dari sumber-sumber yang tidak terbatas. (Ribeiro, 2014).

Kegiatan pembelajaran melalui daring ataupun luring, terjadi pola komunikasi. Pola merupakan pedoman, contoh, model kerja yang dipakai untuk menghasilkan suatu bagian 
untuk pola dasar yang ditujukan atau terlihat yang mana sesuatu itu dikatakan deteksi pola, memamerkan pola yang dinamai dengan identifikasi pola.

Pola komunikasi dapat diartikan sebagai cara seseorang baik individu maupun kelompok dalam melakukan proses komunikasi. Dengan kata lain pola komuniksi adalah proses komunikasi yang dilakukan antara orang-orang yang terlibat dalam proses tersebut. Seperti diungkapkan oleh Josep DeVito bahwa: "Pola Komunikasi adalah suatu gambaran yang sederhana dari proses komunikasi yang memperlihatkan kaitan antara satu komponen komunikasi dengan komponen lainnya" (DeVito: 2007).

1. Communication pattern satu arah, sender (pemberi pesan) dalam hal ini guru menyampaikan pesan kepada murid, dimana murid hanya pasif menerima pesan tanpa terjadi feedback

2. Pola Komunikasi dua arah, sender dan receiver yaitu guru dan murid sama-sama aktif menyampaikan pesan

3. Pola komunikasi banyak arah, bukan hanya guru dan murid yang aktif menyampaikan pesan tetapi terjadi komunikasi yang dinamais antar murid yang satu dengan yang lainnya. (li, 2013)

\section{METODE PENELITIAN}

Deskriptif kualitatif merupakan metode yang digunakan dalam penelitian ini. . Subjek yang diteliti dalam penelitian ini adalah Guru dan Murid di SMK PGRI Larangan dalam melakukan pola komunikasi dengan menggunakan media komunikasi digital (WhatsApp). Subjek terdiri dari Narasumber utama dan narasumber yang telah dipilih peneliti. Narasumber dalam penelitian ini yaitu Bapak Mulyadi Ibu Harjanti, Ranti dan Andi. Sedangkan objek penelitian ini adalah pola komunikasi guru dan murid di SMK PGRI Larangan.

Teknik pengumpulan data dilakukan dengan wawancara dan observasi serta melalui studi kepustakaan. Teknik analisis data dalam penyajian hasil penelitian, peneliti menggunakan deskriptif analisis yaitu:

1. Hasil penelitian diperoleh dari informasi narasumber utama dan narasumber

2. Hasil pengamatan dan data dari beberapa kategori, peneliti analisis secara deskriptif.

3. Masing-masing kategori dikaitkan antara informasi yang satu dengan yang lain dari narasumber-narasumber sebagai jawaban dari masalah pokok penelitian.

Penelitian melakukan penelitian ini pada SMK PGRI Larangan yang berlokasi di Jl. Siswa, Larangan Kota Tangerang, Banten pada Juli 2019 - Januari 2021.

\section{HASIL DAN PEMBAHASAN}

Berdasarkan hasil observasi dan wawancara serta studi Pustaka yang sudah dilakukan terhadap interaksi dan komunikasi antara guru dan murid di SMK PGRI Larangan terdapat beberapa temuan menarik yang peneliti amati.

WhatsApp Group SMK PGRI Larangan menjadi satu-satunya media komunikasi online yang digunakan oleh guru dan murid. Setelah melakukan observasi dan pengamatan langsung, peneliti melihat bahwasanya guru dan murid menggunakan WhatsApp Group sebagai alat komunikasi online. Hampir setiap harinya, guru dan murid menggunakan 
WhatsApp untuk menyebarkan informasi baik seputar pembelajaran maupun hal-hal lain yang bersifat hiburan.

Pola komunikasi pada WhatsApp Group bersifat banyak arah Pada data observasi dapat terlihat bahwa pola komunikasi yang terjadi antara murid dan guru di SMK PGRI Larangan bersifat banyak arah, sebagai contoh ketika guru memberikan informasi berupa materi tidak sedikit murid yang langsung menanggapi apa yang disampaikan oleh guru bahkan sering terjasdi obrolan melalui chat di WhatsApp Group SMK PGRI Larangan.

WhatsApp Group guru dan murid SMK PGRI Larangan cukup efisien sebagai media penyebar informasi. Hasil observasi menunjukkan bahwa materi yang disampaikan oleh guru dan informasi yang disampaikan guru dan murid menggunakan WhatsApp Group cukup efektif, bahkan seringkali terjadi diskusi dalam WhatsApp Group tersebut.

WhatsApp Group menjadi media komunikasi yang sangat nyaman bagi murid SMK PGRI Larangan dibandingkan melalui komunikasi tatap muka. Peneliti melakukan observasi ketika guru dan murid menggunakan komunikasi secara online ataupun langsung tatap muka maupun saat berkomunikasi melalui media komunikasi WhatsApp Group. Hasilnya bahwa murid lebih aktif dan nyaman ketika berkomunikasi menggunakan WhatsApp Group dengan gurunya di SMK PGRI Larangan.

\section{WhatsApp Group Berperan menjadi Inovasi Berkomunikasi antara Guru dan Murid di SMK PGRI}

Komunikasi adalah merupakan proses penyampaian pesan dari komunikator kepada komunikan menggunakan media-media. Dalam proses komunikasi, dapat dilakukan dengan berbagai macam cara, seperti yang dilakukan oleh guru di SMK PGRI. SMK PGRI sebagai sekolah yang mengedepankan kemajuan teknologi dan informasi, kini sudah menganjurkan semua guru dan staf dapat berkomunikasi secara digital, baik dengan siswa, orang tua murid bahkan dengan rekan sejawan yang berada di SMK PGRI. WhatsApp Group dipilih menjadi media yang diyakini mampu menjawab kebutuhan publik di SMK PGRI sebagai inovasi dalam berkomunikasi. WhatsApp Group dianggap sebagai aplikasi yang memudahkan dalam proses penyampaian pesan maupun informasi baik dari guru ke murid maupun guru ke seluruh kelas. Namun beberapa murid di SMK PGRI ada juga yang menggunakan aplikasi Line Group sebagai media penyampaian informasi, dikarenakan Line dianggap lebih mewakili generasi milenial dengan adanya emoticon yang dapat menunjang dalam penyampaian pesan. Dengan penggunaan sosial media WhatsApp informasi yang berkaitan dengan pelajaran serta aktivitas di sekolah menjadi lebih efisien. Selain itu, WhatsApp ataupun Line Group dianggap sebagai media mempererat hubungan antara guru dan murid. kedekatan hubungan yang terjadi antara guru dan murid SMK PGRI Larangan tercermin dari pola komunikasi yang informal serta bahan ataupun topik pembicaraan yang tidak hanya seputar pelajaran tapi juga topik yang dapat menghidupkan suasana grup.

Kemajuan di bidang komunikasi membawa dampak yang sangat besar dalam proses komunikasi antara guru dan murid di SMK PGRI Larangan. Informasi menjadi cepat dan tepat sasaran sehingga murid dapat memahami pesan yang disampaikan. Dengan cepatnya proses penyebaran informasi, membuat siswa menjadi lebih produktif dan efisien, misalnya dalam penyampaian tugas, apabila ada hal yang tidak dimengerti oleh murid dapat di bahas 
melalui WhatsApp Group. Hal ini memungkinkan adanya informasi dan pengetahuan lebih yang bisa diperoleh oleh murid SMK PGRI Larangan.

\section{Pola Komunikasi banyak arah, Sistem Sosial dan Perubahan Norma dalam Proses Komunikasi antara Guru dan Murid SMK PGRI Larangan melalui sosial media WhatsApp Group;}

Kemajuan teknologi komunikasi membawa berbagai dampak, baik itu dampak positif maupun dampak negatif. Dampak positif yang dapat dirasakan dengan adanya kemajuan teknologi komunikasi tentu saja berimbas pada kecepatan dan efisiensi waktu. Namun ternyata dampak negatif juga dapat dirasakan, salah satunya dengan perubahan norma dari murid. Dengan adanya WhatsApp Group, guru dan murid dapat berkomunikasi secara lebih informal, membuat murid lebih mengedepankan sistem keakraban yang menganggap guru sebagai rekan atau teman mereka, sehingga murid cenderung kurang sopan dengan tidak melakukan komunikasi yang seharusnya dan hal ini yang menjadi kekhawatiran bagi guru. Disinilah guru memiliki kewajiban untuk menegur murid tersebut agar tetap mematuhi norma dan peraturan yang berlaku dan hal ini dilakukan juga oleh SMK PGRI Larangan.

Komunikasi yang ada di WhatsApp Group juga dipengaruhi oleh pihak yang berada dalam grup tersebut. Jika guru yang bersngkutan memiliki sikap yang tegas, murid cenderung tidak aktif dan jarang melakukan komunikasi di grup tersebut. Lain halnya bila guru yang menyenangkan, murid akan lebih aktif berkomuniaksi dan membahas berbagai hal di luar konteks pelajaran dan aktivitas di sekolah.

Pola komunikasi banyak arah yang terjadi di WhatsApp Group SMK PGRI Larangan. Dalam wawancara sebelumnya, terlihat pula bahwa murid tidak ragu untuk berkomunikasi dengan guru, maupun berkomunikasi dengan sesama teman di WhatsApp Group. WhatsApp Group dinilai sebagai media yang efektif untuk menyebarkan informasi kepada seluruh murid, baik informasi yang bersifat akademik maupun sekedar hiburan untuk mencairkan suasana antara guru dan murid.

\section{Whatsapp Group memiliki Fungsi Hiburan bagi Guru dan Murid di SMK PGRI Larangan}

Komunikasi melalui media sosial memiliki banyak manfaat, seperti yang terjadi pada WhatsApp Group yang digunakan oleh guru dan murid di SMK PGRI Larangan sebagai sarana komunikasi. Di WhatsApp Group tidak hanya menyampaikan informasi saja melainkan juga adanya nilai hiburan. Dimana terkandang ada candaan yang dilontarkan murid dan guru, yang menciptakan suasan grup yang lebih menyenangkan, hangat dan tidak membosankan. Komunikasi dapat dilakukan di hari biasa maupun di hari libur, pembahasan di luar konteks maupun tentang aktivitas sekolah.

\section{Hambatan Komunikasi Menggunakan WhatsApp Group Antara Guru dan Murid di SMK PGRI Larangan}

Komunikasi yang dilakukan menggunakan WhatsApp Group juga memliki berbagai hambatan. Salah satunya dengan adanya keterbatasan sarana komunikasi maupun koneksi internet. Keterbatasan sarana komunikasi bisa terjadi karena alat komunikasi yang di miliki 
murid rusak, kuota internet yang terbatas dan koneksi jaringan yang tidak memadai di daerah tertentu, sehingga pesan atau informasi yang disampaikan terputus-terputus atau tidak dapat diterima dengan baik oleh semua murid. Guru disini memliki kewajiban untuk selalu menghimbau murid nya untuk selalu up to date informasi yang disampaikan di grup, sehingga semua murid mengerti dan paham dengan komunikasi yang sedang dilakukan secara maksimal. Dan adapula hambatan lainnya yaitu terjadinya misscommunication antara guru dan murid saat membaca pesan melalui WhatsApp Group, hal ini dapat terjadi karena pemahaman yang beragam ketika membaca pesan teks yang tidak memliki intonasi ataupun raut wajah (emoticon) sehingga makna pesan tidak tersampaikan secara baik.

\section{SIMPULAN}

1. WhatsApp menjadi inovasi terbaru dalam sistem komunikasi, yang mana komunikasi dan sistem pembelajaran dengan metode WhatsApp dirasakan mempermudah arus komunikasi dan metode pembelajaran.

2. Perubahan sistem sosial dan norma kesopanan pada interaksi antara guru dan murid dirasakan setelah adanya WhatsApp Group.

3. WhatsApp selain memliki fungsi informatif, ia juga memliki fungsi hiburan, dimana WhatsApp sbagai media yang dapat menyuguhkan interaksi yang menyenangkan antara guru dan murid.

4. Hambatan komunikasi dengan menggunakan WhatsApp Group berdampak pada interaksi dan pesan yang tidak tersampaikan secara maksimal.

5. Berdasarkan hasil analisis data serta hasil wawancara menunjukkan pola komunikasi yang terjadi di dalam grup WhatsApp guru dan Murid SMK PGRI Larangan terjadi banyak arah, baik secara vertikal, horizontal maupun diagonal.

6. Analisis dan hasil wawancara menunjukkan pula, murid merasa lebih fleksibel ketika berkomunikasi dengan guru menggunakan grup WhatsApp ketimbang bertatap muka secara langsung.

\section{UCAPAN TERIMA KASIH}

Penulis mengucapkan terima kasih kepada Dikti yang telah memberikan kesempatan penulis untuk dapat menuangkan ilmu dan pemikiran lewat penelitian. Universitas Budi Luhur yang telah menjadi wadah penulis dalam berkarya sebagai dosen dan peneliti. Kepada ibu DR. Nawiraoh Vera, M.Si yang telah memberikan sumbangsih ilmu dan saran kepada penulis. Kepada Pengelola Jurnal Avant Garde yang telah membantu peneliti dalam memberikan saran sehingga artikel ini dapat diterbitkan.

\section{DAFTAR PUSTAKA}

Devito, Joseph. (2007). The International Communication Book, Eleventh Edition. New York: Person Education,inc

Hamidati, A., dan Junaedi, F. (2011). Komunikasi 2.0 Teoritisasi dan Implikasi.7.

Ii, B. A. B. (2013).933500307-abayusaputra-2013 Pola Komunikasi; produksi program acara; talkshow sakinah. 12-54.

Ii, B. A. B., \& Pustaka,T.(2011). New Media Digital. 12-33. 
KBBI Daring, diakses pada tanggal 9 Februari 2019,pukul 15:50 w.i.b

Kurmia, N. (2005). Perkembangan Teknologi Komunikasi dan Media Baru: Implikasi terhadap Teori Komunikasi. Mediator: Jurnal Komunikasi, 6(2), 291-296. https://doi.org/10/29313/mediator.v6i2.1197.

Littlejhon, Stephen W. \& Foss, Karen A. (2009). Theories of Human

Communications 9 ed, terj. Mohammad Yusuf Hamdan. Jakarta: Salemba Humanika.

Mukaromah, N. (2020). Persepsi Orang Tua Siswa dan Guru Sekolah Dasar Terhadap Pembelajaran Jarak Jauh (Pjj) Berbasis Pembelajaran Daring di Masa Pandemi Covid19. Journal of Chemical Information and Modeling, 53(9), 1689-1699.

Nasrullah, Rulli. (2016).Teori dan Riset Media Siber. Jakarta: Prenada media cetakan

Pratama, M. D., Sinaga, D., \& Radiah, S. (2012). Strategi Komunikasi dalam Penyebaran Informasi di PT Chevron Pacific Indonesia. 1(1), 1-22. http://jurnal.unpad.ac.id/ejournal/article/view/1249/pdf

Puspita, Y. (2015). The Usage of New Media to Simplify Communication and Transaction of Gay Prostitute, Jurnal Pekomnas, 18(3), 203-212.

Setiadi, A. (2016). Pemanfaatan Media Sosial untuk Efektifitas Komunikasi, Jurna; Humaniora, 16(2), 1-7.

SMK PGRI, (n.d.). SMK PGRI Larangan.

Sukmi, S. N. (n.d.). Telaah Pemikiran Holmes tentang Komunikasi, Teknologi dan Masyarakat: 1-23.

Vera, Nawiroh. (2016). Komunikasi Massa. Bogor: Ghalia Indonesia.

Whatsapp,

(n.d.).

No

Title.

https://play.google.com/store/apps/details?id=com.whatsapp\&hl=in\&gl=US 